\title{
LIRA POPULAR
}

\section{LA REVOLUCIÓN DE LOS DICTATORIALES}

\author{
Adolfo Reyes
}

Por formar revolución

Estan los dictatoriales

Sera causa de los males

I ruina de la Nacion.

El domingo a la oracion

Según lo dice "El Chileno."

El plan que hallaban tan bueno

Lo quisieron efectuar

I hubieron de fracasar

En el movimiento pleno.

A la hora de retreta

Se decía en realidad

Que a la oficialidad

Se ultimaría completa

I se a dado con la veta

De la famosa bolina

Cuarto i séptimo de línea

Eran los amenasados

En esa grau Sabatina.

Las cavesillas estaban

En tres grupos divididos

I cada cual reunidos

Ya sus planes preparaban

La hora cruel esperaban

Cuando un piquete llegó
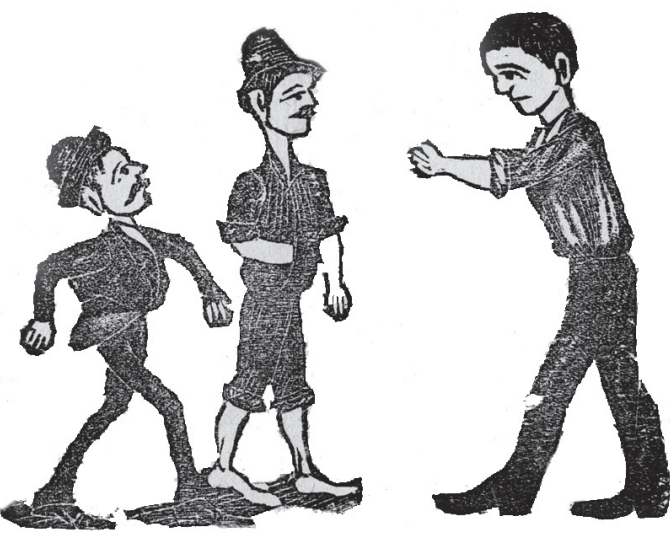

de soldados i los pilló

En ese plan inaudito

I al cuartel mui cayadito

Cada grupo se enserró

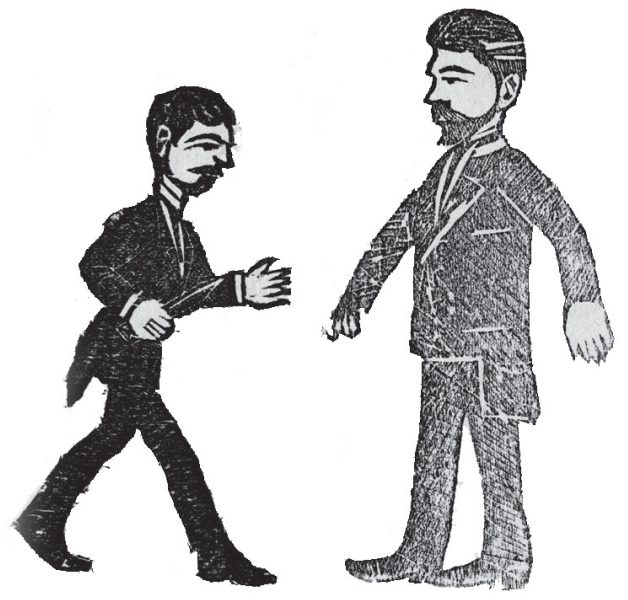

* El presente texto se conserva íntegro, atendiendo a la gramática y ortografía del original. (N. del E.) 
En el lado ultramapocho

Se situaba una cuadrilla I la otra por la orilla de Matucana a las ocho Como comerse un biscocho Hiba a ser la revolución Esta gran conspiración Por cierto fue mal urdida I tal trama consabida A causa admiracion.

Al fin pues público amado Aquí podrás convenserte Que no combiene meterte En semejante atentado Por que el tiempo ya pasado De la tan cruel dictadura



Nos causa tanta amargura I que vuelva nos es posible La guerra será terrible Si evitar no se procura.

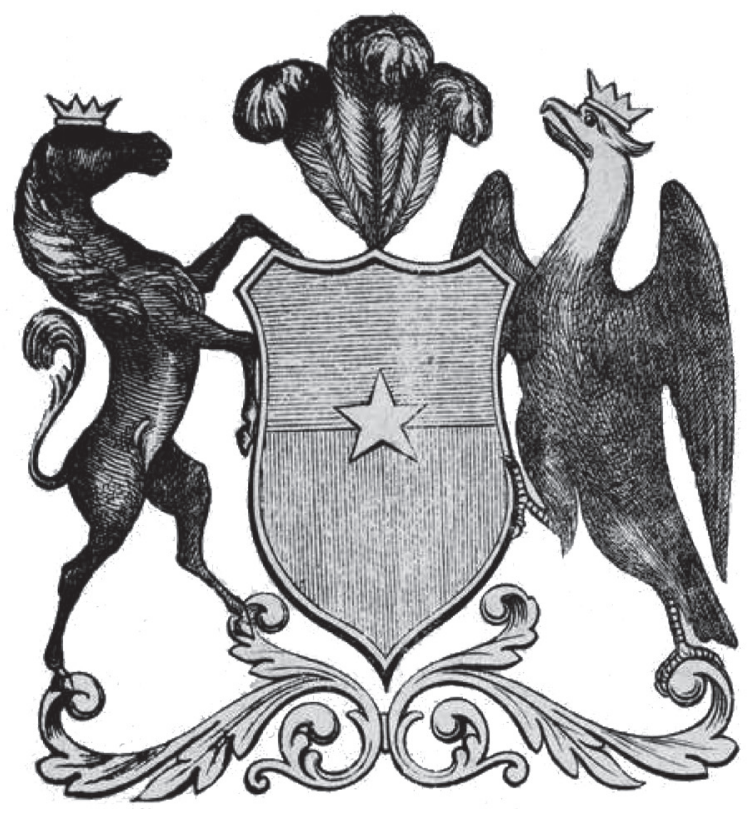

